\title{
Development of an Enzyme-Linked Immunosorbent Assay for Serum 11-Dehydrocorticosterone in Rat and Mouse
}

\author{
Noriko Tagawa, ${ }^{*}$ Nao Ikariko, Keiko Fukumura, and Yoshiharu Kobayashi \\ Department of Medical Biochemistry, Kobe Pharmaceutical University; 4-19-1 Motoyamakita-machi, Higashinada-ku, \\ Kobe 658-8558, Japan. Received May 26, 2006; accepted November 29, 2006; published online December 4, 2006
}

\begin{abstract}
We have developed an enzyme-linked immunosorbent assay (ELISA) for serum 11-dehydrocorticosterone (4-pregnen-21-ol-3,11,20-trione). The antiserum against 11-dehydrocorticosterone 21-hemisuccinate-conjugated bovine serum albumin was raised in rabbits. As an enzyme-labeled antigen, 11-dehydrocorticosterone 21hemisuccinate was conjugated to horseradish peroxidase. Two ELISA systems were established: one without the extraction of steroids from serum (direct method), and another that used an HPLC purification step (HPLC method). The cross-reactivity of all steroids tested against the antibody was low except cortisone (92\%); however, since cortisone levels in rats and mice are negligible, cortisone does not interfere with this direct ELISA. The measurable range of serum 11-dehydrocortiocosterone in both the direct and HPLC methods was $0.3-250 \mathrm{ng} / \mathrm{ml}$ and $0.78-400 \mathrm{ng} / \mathrm{ml}$, respectively. Both methods displayed satisfactory parallel dilution, recovery and reproducibility; moreover, the values obtained with each method significantly correlated with the alternate method. To evaluate the two ELISA systems, the serum concentrations of 11-dehydrocorticosterone in normal rats and mice were determined by these two systems. The levels in Wistar rats fluctuated from 3 to 14 weeks of age $(7.8 \pm 2.6 \mathrm{ng} / \mathrm{ml})$ but at 1 week $(1.7 \pm 1.2 \mathrm{ng} / \mathrm{ml})$ were significantly low compared to other ages. No sex differences were found in rats and mice. Further, using the proposed direct method, chronological changes of rat serum 11dehydrocorticosterone levels after 11-dehydrocorticosterone administration have been investigated together with corticosterone levels. These results verify that the proposed ELISA for 11-dehydrocorticosterone is useful for measuring $11 \beta$-HSD activities in combination with the determination of serum corticosterone in rats and mice.
\end{abstract}

Key words 11-dehydrocorticosterone; enzyme immunoassay; 11beta-hydroxysteroid dehydrogenase; rat; mouse; serum

Glucocorticoids are involved in the regulation of metabolic processes of carbohydrate, lipid and protein, and have an almost systemic effect, e.g., blood pressure, immune system, nervous system and stress. Glucocorticoid levels in the blood circulation are controlled by a negative feedback mechanism of the hypothalamic-pituitary-adrenal axis. On the other hand, in peripheral tissues, intracellular levels of glucocorticoid are regulated by two isozymes, $11 \beta$-hydroxysteroid dehydrogenase type 1 and type 2 (11 $\beta$-HSD- 1 and $11 \beta$-HSD-2). They catalyze the interconversion of biologically inert 11-keto-steroid (11-dehydrocorticosterone or cortisone) and active 11-oxo-glucocortiocoids (corticosterone or cortisol). $11 \beta$-HSD-1, which exists in the liver, adipose tissue, brain, lung and gonads, reduces the carboxyl group at the $\mathrm{C}-11$ position to a hydroxyl group to increase active intracellular glucocorticoid levels. Conversely, $11 \beta$-HSD-2 oxidizes the hydroxyl to a carboxyl group at the C-11 position in the distal nephron, colon and sweat glands to protect the mineralocorticoid receptor from binding abundant glucocorticoid in the circulation. $^{1-4)}$

$11 \beta$-HSDs modulate the intracellular levels of active glucocorticoid, which exerts physiological effects, as described above. Thus, the disruption of their enzymatic regulation in peripheral tissues induces various diseases, for example, increased $11 \beta$-HSD- 1 activity in the adipose tissues and liver is linked to metabolic syndrome, including obesity, insulin resistance and hypertension, ${ }^{1,2,5,6)}$ and decreased or deficient $11 \beta$-HSD-2 in the renal tubules causes hypertension and apparent mineralocorticoid excess. ${ }^{7-9)}$ Therefore, it is clinically important to evaluate the activity of $11 \beta$-HSD- 1 and $11 \beta$ HSD-2 in vivo; however, it is difficult to measure these activities directly in the tissues in vivo. One alternative is to measure the ratios of serum concentrations of cortisol and corti- sone after the oral administration of cortisone acetate under the suppression of endogenous cortisol by dexamethasone. ${ }^{10-12)}$ In mice and rats, which are the most conventional and standard experimental animals, cortisol and cortisone in humans correspond to corticosterone and 11-dehydrocorticosterone, respectively. Therefore, the determination of serum corticosterone and 11-dehydrocorticosterone levels is required to measure $11 \beta$-HSD activity in these animals ${ }^{13)}$; however, no convenient and useful enzyme immunoassay for 11-dehydrocorticosterone is available to date. ${ }^{14,15)}$ In this paper, we described ELISA for serum 11-dehydrocorticosterone and also investigated the developmental changes of serum 11-dehydrocorticosterone levels in rats and mice, and using the proposed ELISA, chronological changes of serum 11-dehydrocorticosterone levels after 11-dehydrocorticosterone administration to rats have been determined. Serum corticosterone levels were also measured in these rats. The results indicate that the proposed ELISA for 11-dehydrocorticosterone is useful for measuring $11 \beta$-HSD activities in combination with the determination of serum corticosterone in rats and mice.

\section{MATERIALS AND METHODS}

Animals Domestic albino rabbits (15 weeks old, male, body weight $2.6-2.8 \mathrm{~kg}$ ), pregnant (day 15 or 17) Wistar rats and ddY mice $(3,7,11$ and over 24 weeks old, male and female) were obtained from Japan SLC, Inc. (Shizuoka, Japan). They were raised in an air-conditioned $\left(23 \pm 1{ }^{\circ} \mathrm{C}\right.$ and $55 \pm 5 \%$ humidity) and light-controlled (lights on 7:00 a.m. to 7:00 p.m.) animal room. The rat pups were born on day 21 of gestation, and the litters were kept in single cages with their mothers until weaning (at three weeks old). The pups were 
then separated into pairs of the same sex, and had free access to standard rat chow and drinking water. These rats were sacrificed at 1 week of age (body weight: male, $10.6 \pm 1.2 \mathrm{~g}$; female, $10.9 \pm 0.6 \mathrm{~g}$ ), 3 weeks of age (male, $37.9 \pm 6.0 \mathrm{~g}$; female, $36.0 \pm 7.2 \mathrm{~g}$ ), 7 weeks of age (male, $168.5 \pm 3.3 \mathrm{~g}$; female, $138.3 \pm 6.6 \mathrm{~g}$ ) and 14 weeks of age (male, $300.0 \pm 3.3 \mathrm{~g}$; female, $178.3 \pm 12.2 \mathrm{~g}$ ). To avoid the increase of serum levels of steroids, especially corticosterone, by ether vapor stress, rats were placed for $30 \mathrm{~s}$ in a jar containing an ether-dampened paper at the bottom of the jar. Blood was obtained within 2 min by puncturing the abdominal aorta. ${ }^{16}$ To achieve adequate volumes to complete the analysis, blood samples had to be pooled in the 1-week-old rats ( 2 or 3 rats /pool); at later ages, blood samples from individual rats were sufficient for analysis.

The mice were sacrificed by decapitation after a resting period of 1 week (body weight, male/female: 4 weeks of age, $22.9 \pm 1.0 \mathrm{~g} / 20.7 \pm 1.3 \mathrm{~g} ; 8$ weeks of age, $36.6 \pm 1.9 \mathrm{~g} / 28.5 \pm$ $0.5 \mathrm{~g} ; 12$ weeks of age, $41.8 \pm 1.7 \mathrm{~g} / 26.5 \pm 1.0 \mathrm{~g}$; over 24 weeks of age, $46.2 \pm 1.7 \mathrm{~g} / 31.3 \pm 1.3 \mathrm{~g}$ ). Serum samples were obtained by centrifugation and serum was stored at $-20^{\circ} \mathrm{C}$ until used for assay.

The experimental procedure was approved by the Kobe Pharmaceutical University Animal Care and Use Committee.

Animal Experiments Previous day of the experiments, blood samples $(0.1-0.15 \mathrm{ml})$ of 4 Wistar rats (9 weeks of age, male, $232 \pm 11 \mathrm{~g}$ ) under light-ether-anesthesia were collected into a capillary tube by needle puncture of tail-vein. Before twelve hours of 11-dehydrocorticosterone administration, the rats were injected dexamethasone sodium phosphate ( $5 \mathrm{mg} / \mathrm{kg}$ as dexamethasone) subcutaneously to suppress endogenous glucocorticoid secretion. Then, 11-dehydrocorticosterone in olive oil was administered orally to the rats (treated group: $4 \mathrm{mg} / \mathrm{ml}, 10 \mathrm{mg} / \mathrm{kg}, n=2$; control group: vehicle, $n=2)$ under pentobarbital $(40 \mathrm{mg} / \mathrm{kg})$ anesthesia. Immediately before the 11-dehydrocorticosterone administration, and at 15, 30, 90 and 120 min after the treatment, blood samples were collected as above. Obtained serum samples were stored at $-30{ }^{\circ} \mathrm{C}$ until assayed.

Materials The sources of materials were as follows: authentic steroids from Steraloids Inc. (RI, U.S.A.); anti-rabbit IgG (whole molecule) developed in goat and 1-ethyl-3-(3-dimethylaminopropyl)carbodiimide $\mathrm{HCl}$ (EDAC) and bovine serum albumin (BSA) from Nacalai Tesque (Kyoto, Japan); horseradish peroxidase (HRP, EC 1.11.1.7) from SIGMA (MO, U.S.A.); 3,3',5,5'-tetramethylbenzidine (TMB) solution for the substrate of peroxidase from KPL Inc. (MD, U.S.A.); $\operatorname{Oasis}^{\circledR}$ MAX cartridge (size: $1 \mathrm{ml} / 30 \mathrm{mg}$ ) from Waters Corporation (MA, U.S.A.); Costar E.I.A./R.I.A. 8-Well Strip (flat bottom) from Corning Inc. (NY, U.S.A.); Decadron $^{\circledR}$ phosphate injection (dexamethasone sodium phosphate) from Banyu Pharmaceutical Co., Ltd. (Tokyo, Japan).

HPLC Conditions The HPLC system used was composed of the following modules: 2 pumps (model 510); a UV detector (model 486) operating at $210 \mathrm{~nm}$; an autosampler (model 717); Millennium V.2.18 chromatography software (all from Waters); and a Mightysil, RP-18 GP, $250 \mathrm{~mm} \times$ $4.6 \mathrm{~mm}$ I.D. column, $5 \mu \mathrm{m}$ particle size (Kanto Chemical Co., Inc., Tokyo, Japan). The column temperature was stabilized at $40{ }^{\circ} \mathrm{C}$ and the flow rate was set at $1 \mathrm{ml} / \mathrm{min}$. The col- umn was immediately eluted with a stepwise gradient from initial conditions, water-acetonitrile $(65: 35, \mathrm{v} / \mathrm{v} \%)$ to final conditions, water-acetonitrile $(20: 80, \mathrm{v} / \mathrm{v} \%)$ in $30 \mathrm{~min}$, followed by a $5 \mathrm{~min}(30-35 \mathrm{~min})$ run with the final conditions. At the end of each run, the mobile phase solvent reverted to the initial composition, and the column was equilibrated for $40 \mathrm{~min}$ prior to the next run. Total analytical time was $75 \mathrm{~min} /$ cycle.

Preparation of Immunogen for 11-Dehydrocorticosterone Antibody 11-Dehydrocorticosterone 21-hemisuccinate was conjugated to BSA by the mixed-anhydride method. ${ }^{17,18)}$ Briefly, $8 \mathrm{mg}$ of 11-dehydrocorticosterone 21hemisuccinate was dissolved in a solution containing $0.2 \mathrm{ml}$ of dimethyl formamide (DMF) and $5 \mu \mathrm{l}$ of tri- $n$-butylamine, and the solution was cooled to $10^{\circ} \mathrm{C}$. After the addition of $3 \mu \mathrm{l}$ of isobutyl chlorocarbonate, the solution was stirred at $4{ }^{\circ} \mathrm{C}$ for $20 \mathrm{~min}$. This steroid solution was added dropwise to BSA solution, which was prepared as follows: $40 \mathrm{mg}$ of BSA was dissolved in $1.15 \mathrm{ml}$ of distilled water adjusted to approximately $\mathrm{pH} 9.5$ with $1 \mathrm{M} \mathrm{NaOH}$ and after the addition of $1.0 \mathrm{ml}$ of DMF cooled at $4^{\circ} \mathrm{C}$. The reaction mixture was stirred at $4{ }^{\circ} \mathrm{C}$ for $4.5 \mathrm{~h}$. The 11-dehydrocorticosterone-BSA conjugate and unbound steroid was separated by Sephadex G-25 fine $(25 \mathrm{~cm} \times 1 \mathrm{~cm}$ I.D.) eluted with saline. The proteinous fraction (eluted from $18 \mathrm{ml}$ to $24 \mathrm{ml}$ ) detected by Bio-Rad Protein assay (Bio-Rad Laboratories, CA, U.S.A.) was collected and the protein concentration was quantified by Bio-Rad Protein assay with BSA as a standard according to the manufacturer's instructions. The molar number of steroid bound to BSA was measured by UV absorption spectrometry. ${ }^{19)}$

Production of Antiserum and Preparation of Immunoglobulin Fraction A $2 \mathrm{ml}$ saline solution containing $1 \mathrm{mg}$ of 11-dehydrocorticosterone 21-hemisuccinate-BSA was emulsified with $2 \mathrm{ml}$ of Freund's complete adjuvant. For immunization the emulsion was given to rabbits in multiple $1 \mathrm{ml}$ injections subcutaneously on the back. Booster injections were given at 2-week intervals using the same dosage as the first immunization. Antisera were obtained from three rabbits 10 weeks after the first immunization. One of the three antisera, with a higher specificity and titer, was chosen for use in this study. Anti-BSA antibody was removed from the antiserum using a BSA immobilized Sepharose 4B column prepared with CNBr-activated Sepharose 4B (Amersham Pharmacia Biotech AB, Uppsala, Sweden) according to the manufacturer's instructions. Next, the immunoglobulin fraction was purified using a Protein A Sepharose 4 Fast Flow column (Amersham Pharmacia Biotech AB) and followed desalting by a PD-10 column (Amersham Pharmacia Biotech AB). Before use, the antiserum was diluted $1: 60000$ with $0.1 \%$ gelatin PBS.

Preparation of HRP-Labeled 11-Dehydrocorticosterone HRP-labeled 11-dehydrocorticosterone was prepared by a carbodiimide method. ${ }^{20)}$ A solution containing $1 \mathrm{mg}$ of 11 dehydrocorticosterone 21-hemisuccinate in $0.3 \mathrm{ml}$ of DMF was stirred with $1 \mathrm{mg}$ of EDAC at room temperature for $1 \mathrm{~h}$. This reaction mixture was then added dropwise with stirring to a mixture of $5 \mathrm{mg}$ of HRP and $0.5 \mathrm{ml}$ of $0.05 \mathrm{M} \mathrm{NaH}_{2} \mathrm{PO}_{4}-$ $\mathrm{Na}_{2} \mathrm{HPO}_{4}$ buffer ( $\mathrm{pH}$ 8.0). The tube was allowed to stand at room temperature with gentle stirring for $3 \mathrm{~h}$. The resulting solution was then applied to a Sephadex G-25 fine column 
$(25 \mathrm{~cm} \times 1 \mathrm{~cm}$ I.D. $)$ and eluted with $0.067 \mathrm{M} \quad \mathrm{NaH}_{2} \mathrm{PO}_{4}-$ $\mathrm{Na}_{2} \mathrm{HPO}_{4}$ buffer ( $\mathrm{pH}$ 7.4). The fractions containing HRP-labeled 11-dehydrocorticosterone (eluted from $18-24 \mathrm{ml}$ ) were collected and stored at $4{ }^{\circ} \mathrm{C}$. Before use, the fractions were diluted 1:51200 with $0.1 \%$ gelatin PBS. As described in the section of immunogen preparation, the molar number of steroids bound to HRP was calculated by UV absorption spectrometry. ${ }^{19)}$

Preparation of Serum Calibrators A serum calibrator for 11-dehydrocorticosterone was prepared by adding authentic 11-dehydrocorticosterone to steroid-free serum. A stock solution of authentic 11-dehydrocorticosterone, $0.5 \mathrm{mg} /$ $\mathrm{ml}$, in ethanol was serially diluted with ethanol as ethanol calibrators. To prepare serum steroid calibrators containing 11 -dehydrocorticosterone $(0.05-1600 \mathrm{ng} / \mathrm{ml})$, an aliquot of the ethanol calibrators was placed in tubes and evaporated. Charcoal-stripped steroid-free serum ${ }^{21)}$ was then added and vortexed thoroughly.

Extraction of Steroids From Serum Sample In the HPLC method, 11-dehydrocorticosterone was extracted from serum according to the method described previously. ${ }^{22,23)}$ Briefly, $0.05 \mathrm{ml}$ of serum samples or serum calibrators containing authentic 11-dehydrocorticosterone standard were treated with $1 \mathrm{ml}$ of $0.6 \%$ glutamic acid aqueous solution at $60{ }^{\circ} \mathrm{C}$ for $10 \mathrm{~min}^{24)}$ The solution was cooled to room temperature and applied to a solid phase extraction column, Oasis ${ }^{\circledR}$ Max cartridge, which was pretreated with $1 \mathrm{ml}$ of methanol and $1 \mathrm{ml}$ of water. The cartridge was washed twice with $1.3 \mathrm{ml}$ of water and the unconjugated steroids were eluted with $3 \mathrm{ml}$ of $72 \%$ methanol. The resultant unconjugated fraction was evaporated in vacuo. The residue was then dissolved in $0.3 \mathrm{ml}$ of the HPLC mobile phase, water : acetonitrile (65: $35, \mathrm{v} / \mathrm{v})$, and $0.25 \mathrm{ml}$ of the sample was injected into the HPLC to fractionate 11-dehydrocorticosterone. The eluate between 10.3 and $12.3 \mathrm{~min}$ (11-dehydrocorticosterone retention time, $11.0 \mathrm{~min}$ ) was collected and the solvent was evaporated under reduced pressure. The residue was reconstituted in $0.5 \mathrm{ml}$ of methanol. Aliquots of this solution $(0.06$ $0.2 \mathrm{ml}$ ) were transferred to a tube. After evaporation of the solvent, the obtained residue was submitted to the ELISA described below to quantify serum 11-dehydrocorticosterone concentrations.

Preparation of ELISA Plate For the separation of bound and free enzyme labeled antigen (B/F separation) an ELISA microtiter plate pre-coated with immobilized second antibody was prepared. The microtiter plates were coated with $0.1 \mathrm{ml}$ per well of goat anti-rabbit IgG antibody $(15 \mu \mathrm{g} /$ $\mathrm{ml}$ in $0.1 \%$ gelatin PBS) at $4{ }^{\circ} \mathrm{C}$ overnight. The next day, the coating solution was thawed from the well and the plates were blocked with $0.3 \mathrm{ml}$ per well of $0.1 \%$ gelatin PBS at room temperature for more than $2 \mathrm{~h}$. The plates were then emptied and rinsed with $0.3 \mathrm{ml}$ per well of $0.05 \%$ Tween 20 in PBS. ELISA plates were filled with $0.05 \%$ Tween 20 in PBS and stored at $4{ }^{\circ} \mathrm{C}$ until used.

ELISA Procedure for the HPLC Method To tubes containing serum sample or serum calibrator purified by HPLC as above, $0.5 \mathrm{ml}$ of HRP-labeled 11-dehydrocorticosterone (1:51200 dilution) and $0.2 \mathrm{ml}$ of anti-11-dehydrocorticosterone antibody (1:60000 dilution), diluted with $0.1 \%$ gelatin in PBS, were added, mixed and incubated at room temperature for $2 \mathrm{~h}$. Then, $0.1 \mathrm{ml}$ of the reaction mixture was transferred to the ELISA plate $(n=2)$, and left to stand at $4{ }^{\circ} \mathrm{C}$ overnight. The following day, the plates were washed three times with $0.3 \mathrm{ml}$ of PBS, and then HRP activities were measured. A $0.1 \mathrm{ml}$ of TMB substrate was added and shaken slowly on a vortex shaker equipped with a platform head to hold microtiter plates at room temperature for $20 \mathrm{~min}$. The enzymatic reaction was stopped by the addition of $0.1 \mathrm{ml}$ per well of $10 \%$ phosphoric acid aqueous solution, and optical density at $450 \mathrm{~nm}$ was measured by microplate reader (Thermoelectrone Ltd., Finland). The absorbance values were converted into 11-dehydrocorticosterone concentrations by a computer program, Genesis Lite version 3.03 (Life Science, U.K.).

ELISA Procedure for Direct Method In the tubes, $6.25 \mu \mathrm{l}$ of serum samples or calibrators were mixed with $0.1 \mathrm{ml}$ of $0.1 \%$ gelatin PBS containing $1 \%$ sodium salicylate, and left to stand at room temperature for $1 \mathrm{~h}^{25)}$ ELISA was then performed as above except for the addition of $0.1 \mathrm{ml}$ of anti-11-dehydrocorticosterone antibody (1:30000 dilution). Fifty microliters of HRP-labeled 11-dehydrocorticosterone (1:51200 dilution) and $0.1 \mathrm{ml}$ of anti-11-dehydrocorticosterone antibody were added. After standing for $2 \mathrm{~h}, 0.1 \mathrm{ml}$ of the reaction mixture was transferred to the ELISA plate $(n=2)$, and B/F separation and HRP activity measurement were performed similarly to the HPLC method as above.

Statistical Analysis We tested for significant differences between male and female rats of each week of age using the Mann-Whitney $U$-test. The steroid levels at ages 1, 3 and 7 weeks were compared with those at 14 weeks between the sexes using the Dunnett test. $p<0.05$ was considered significant.

\section{RESULTS AND DISCUSSION}

Molar Number of the Steroid Bound to BSA and HRP Prior to immunization, the molar number of the steroid, 11dehydrocorticosterone, bound to BSA was estimated using ultraviolet spectrophotometry according to a method described by Erlanger. ${ }^{19)}$ Eighteen moles of 11-dehydrocorticosterone were bound to one mole of BSA. On the other hand, it was determined that 5.4 moles of 11-dehydrocortiocosterone were bound to one mole of HRP. It has been estimated that the number of steroid molecules covalently linked to the BSA molecule by the mixed-anhydride method was approximately $20^{19)}$ and that the molar ratio of the HRP/ steroid did not influence the sensitivity of the assay, whereas enzyme labeling was performed by the $N$-succinimidyl ester method. ${ }^{26)}$ Taking these into account, both of the prepared BSA and HRP conjugates were valid for establishing ELISA.

Calibration Curves, Sensitivity, Specificity and Recovery for ELISA Typical calibration curves for ELISA with HPLC purification and direct ELISA are shown in Fig. 1. The minimal detectable amount of 11-dehydrocortiocosterone, calculated from -2 standard deviation at the zero concentration of 11-dehydrocortiocosterone $(n=5)$, was $0.25 \mathrm{pg}$ / assay ( $0.726 \mathrm{fmol} /$ assay) and $1.95 \mathrm{pg} /$ assay (5.66 fmol/assay), respectively. The measurable range of serum 11-dehydrocortiocosterone was $0.3-250 \mathrm{ng} / \mathrm{ml} \quad(0.09-726 \mathrm{nmol} / \mathrm{l})$ by ELISA with the HPLC method and $0.78-400 \mathrm{ng} / \mathrm{ml}(2.27-$ $1161 \mathrm{nmol} / \mathrm{l})$ with the direct method. The specificities of the anti-11-dehydrocortiocosterone antiserum are summarized in 
Table 1. The cross-reactivity of the antibody against the steroids tested was very low, except for cortisone. However, cortisone levels in rats and mice are negligible; therefore, corticone does not interfere with this direct method. Accuracy was estimated from the recovery study. A known concentration of 11-dehydrocorticosterone was added to two fractions of rat pooled serum. After spiking, the concentration of 11-dehydrocorticosterone was measured by ELISA with the HPLC method and direct method. Sample recovery by both methods exceeded $97 \%$ (Table 2 ).

Serial Dilution Study Three rat serum samples were serially diluted with charcoal-stripped steroid-free serum. As shown in Fig. 2, a linear line, which passed through the zero point, was obtained between the dilution and 11-dehydrocortiocosterone concentrations for each sample by both methods.

Precision Intra- and Inter-assay Variance The intraand inter-assay coefficients of variation (C.V., $n=4)$ by HPLC method purification were less than $6.2 \%$ and $10 \%$, respectively. Those by direct ELISA were $2.0-3.3 \%$ and $6.2-8.0 \%$, respectively.

Comparison of HPLC Method and Direct Method To investigate the reliability of the direct method, the values of rat serum 11-dehydrocorticosterone $(n=16)$ measured by the direct method were compared with those obtained by the HPLC method. As shown in Fig. 3, there was good correlation between the values obtained by the two methods (Pearson's correlation efficient: $r=0.990, p<0.001, y=1.09 x+$ $0.32, n=16)$.

Developmental Changes of the Serum Levels of 11-Dehydrocortiocosterone in Rats and Mice During postnatal

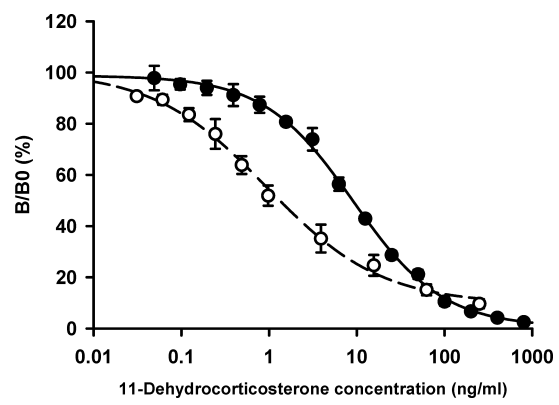

Fig. 1. Calibration Curves for Serum 11-Dehydrocortiocosterone ELISA by HPLC and Direct Methods

Calibration curves by HPLC method (open circle and dashed line) and direct method (closed circle) were obtained by plotting B/B0 (\%) versus the 11-dehydrocortiocosterone amount on a logarithmic scale. Results are expressed as the mean \pm S.D. $(n=4)$
Table 1. Percent Cross-Reactivity of the Anti-11-dehydrocortiocosterone Antiserum

\begin{tabular}{lc}
\hline \hline \multicolumn{1}{c}{ Steroids } & Cross-reactivity (\%) \\
\hline 11-Dehydrocortisone & 100.0 \\
Cortisone & 92.0 \\
Aldosterone & 1.84 \\
11-Deoxycorticosterone & 1.60 \\
Progesterone & 1.50 \\
Estradiol & 0.74 \\
17 $\alpha$-Hydroxyprogesterone & 0.74 \\
11-Desoxycortisol & 0.70 \\
Testosterone & 0.70 \\
Corticosterone & 0.56 \\
4-Androstenedione & 0.50 \\
Cortisol & 0.32 \\
Pregnenolone & $<0.04$ \\
Androstenediol & $<0.004$ \\
Dexamethasone & $<0.0013$ \\
Dehydroepiandrosterone & $<0.0004$ \\
\hline
\end{tabular}

The percent cross-reaction was calculated as follows: If $x=$ picograms of 11-dehydrocortiocosterone required to displace $50 \%$ of HRP-labeled 11-dehydrocortiocosterone bound to the antibody and $y=$ picograms of steroid tested required to displace $50 \%$ of HRP-labeled 11-dehydrocortiocosterone bound to the antibody, then the percent crossreaction of steroid tested $=(x / y) \times 100$.

Table 2. Recoveries of 11-Dehydrocorticosterone from Exogenously Spiked Pooled Serum

a) HPLC method

\begin{tabular}{ccccc}
\hline \hline \multicolumn{2}{c}{ Serum } & 11-dehydrocorticosterone concentration $(\mathrm{ng} / \mathrm{ml})$ & \\
\cline { 1 - 2 } Added & Expected & $\begin{array}{c}\text { Observed } \\
\text { Recovery } \\
(\text { mean } \pm \text { S.D.) }\end{array}$ & $n$ & \\
\hline 0 & & $4.9 \pm 0.5$ & & \\
1.2 & 6.1 & $6.1 \pm 1.2$ & 6 & 102.9 \\
6.0 & 10.9 & $10.8 \pm 1.4$ & 6 & 99.0 \\
30.0 & 34.9 & $34.2 \pm 6.7$ & 6 & 97.0 \\
\hline
\end{tabular}

b) Direct method

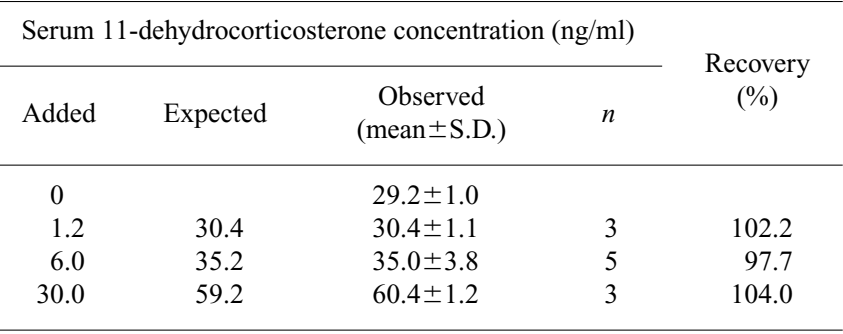

An aliquot $(20 \mu \mathrm{l})$ of authentic 11-dehydrocorticosterone methanol solution (concentration: $24 \mathrm{ng} / \mathrm{ml}, 120 \mathrm{ng} / \mathrm{ml}$ or $600 \mathrm{ng} / \mathrm{ml}$ ) was placed in a tube. After evaporation, rat pooled serum $(400 \mu \mathrm{l})$ was added and stirred at $4{ }^{\circ} \mathrm{C}$ overnight.
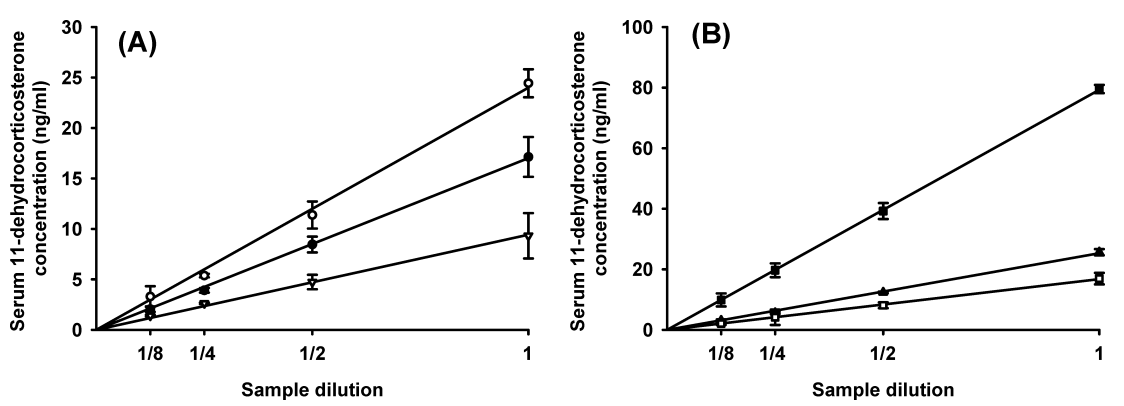

Fig. 2. Serum Dilution Study

Rat serum samples (open circle, 1 ; closed circle, 2 ; open triangle, 3 ; closed triangle, 4 ; open square, 5 ; closed square, 6 ) were serially diluted with charcoal-stripped steroid-free serum, and measured by developed ELISA using HPLC (A) and with the direct method (B). Results are expressed as the mean \pm S.D. $(n=2-4)$ 
development (2-10 d after birth), rats and mice undergo a period of reduced stress responsiveness, the so-called stress hypo-responsive period (SHRP), ${ }^{27)}$ and stimulation of corticosterone secretion by $\mathrm{ACTH}$ is very low. ${ }^{28)}$ It is reported that the serum corticosterone circadian rhythm, which is due to the diurnal variation of adrenal responsiveness to ACTH, is not established before $16 \mathrm{~d}$ of age. ${ }^{29)}$ Moreover, it is known that plasma corticosterone concentrations are extremely low in newborn rats. ${ }^{30,31)}$ We also confirmed that the serum levels of corticosterone at 1 week were markedly low compared with those throughout $1-14$ weeks of age. ${ }^{32)}$ Thus, it is conceivable that low serum 11-dehydrocorticosterone levels may also seen at immediately after birth due to SHRP. Therefore, developmental changes of serum 11-dehydrocorticosterone levels in Wistar rats were measured by HPLC and direct methods. Rats were selected at the ages of $1,3,7$, and 14

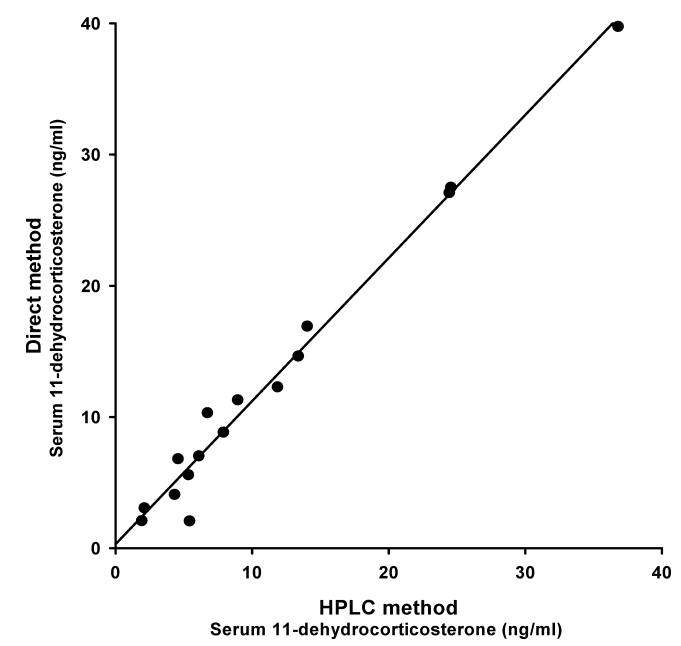

Fig. 3. Comparison of Rat Serum Concentrations of 11-Dehydrocorticosterone Measured between the HPLC Method and Direct Method
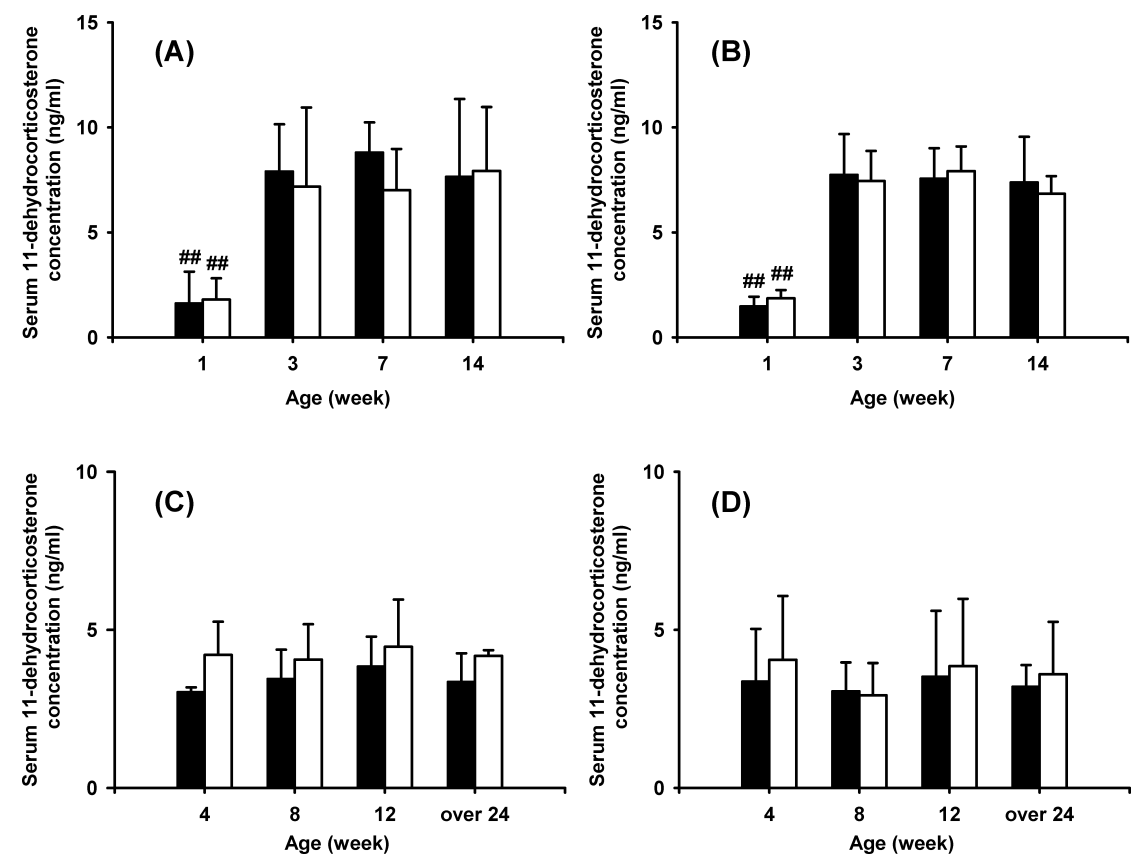

Fig. 4. Changes in the Serum Concentrations of 11-Dehydrocorticosterone during Development in Wistar Rats (A and B) and ddY Mice (C and D)

Serum levels were measured by HPLC (A and C) and direct methods (B and D). Results are expressed as the mean \pm S.D. $(n=4-6)$. \# $p<0.01 v s$. 14 weeks of age in same gender (Dunnett test). Filled bar, male; open bar, female. 

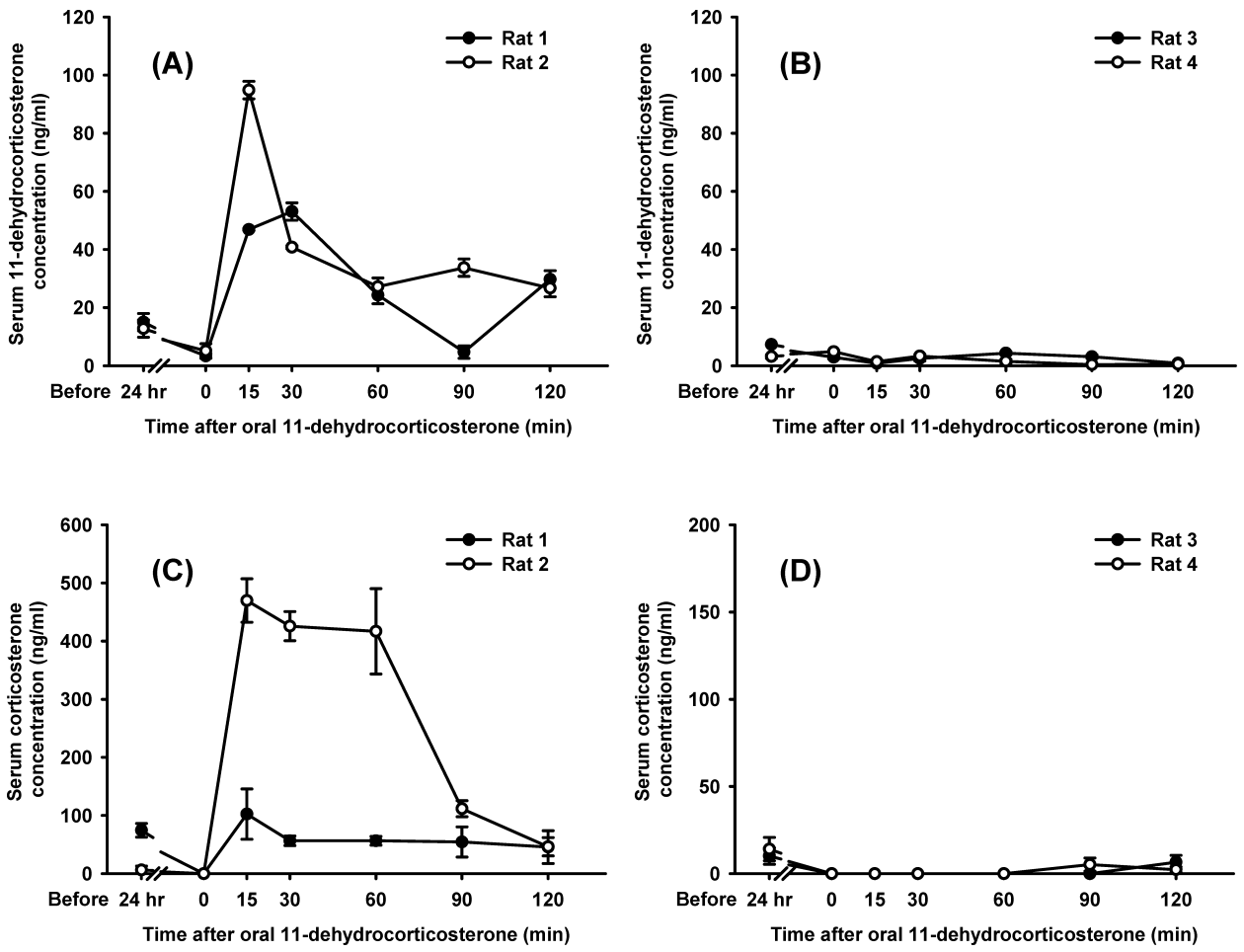

Fig. 5. Chronological Changes of the Serum Concentrations of 11-Dehydrocorticosterone (A and B) and Corticosterone (C and D) after Oral Administration of 11-Dehydrocorticosterone to Rats.

Nine-week-old male Wistar rats were orally administered 11-dehydrocorticosterone ( $40 \mathrm{mg} / \mathrm{kg}$ ) dissolved in olive oil (A and C) or vehicle (B and D). Endogenous glucocorticoid secretion was suppressed by subcutaneous injection of dexamethasone at $12 \mathrm{~h}$ before administration of 11-dehydrocorticosterone. Serum steroid levels were measured by direct methods. Results are expressed as the mean \pm S.D. $(n=2)$

Table 3. Intra- and Inter-assay Variation of 11-Dehydrocorticosterone Control Samples as Measured by Developed ELISA

a) HPLC method

\begin{tabular}{|c|c|c|c|c|c|c|c|}
\hline \multirow{3}{*}{$\begin{array}{c}\text { Samples } \\
\text { no. }\end{array}$} & \multicolumn{3}{|c|}{ Intra-assay } & \multirow{3}{*}{$\begin{array}{c}\text { Samples } \\
\text { no. }\end{array}$} & \multicolumn{3}{|c|}{ Inter-assay } \\
\hline & \multicolumn{3}{|c|}{ 11-Dehydrocorticosterone $(\mathrm{ng} / \mathrm{ml})$} & & \multicolumn{3}{|c|}{ 11-Dehydrocorticosterone (ng/ml) } \\
\hline & Mean \pm S.D. & C.V. $(\%)$ & $n$ & & Mean \pm S.D. & C.V. $(\%)$ & $n$ \\
\hline 1 & $1.96 \pm 0.12$ & 6.2 & 4 & 4 & $1.86 \pm 0.13$ & 6.9 & 4 \\
\hline 2 & $6.78 \pm 0.39$ & 5.8 & 4 & 5 & $7.68 \pm 0.63$ & 8.2 & 4 \\
\hline 3 & $9.34 \pm 0.51$ & 5.4 & 4 & 6 & $29.2 \pm 2.91$ & 10.0 & 4 \\
\hline
\end{tabular}

b) Direct method

\begin{tabular}{|c|c|c|c|c|c|c|c|}
\hline \multirow{3}{*}{$\begin{array}{c}\text { Samples } \\
\text { no. }\end{array}$} & \multicolumn{3}{|c|}{ Intra-assay } & \multirow{3}{*}{$\begin{array}{c}\text { Samples } \\
\text { no. }\end{array}$} & \multicolumn{3}{|c|}{ Inter-assay } \\
\hline & \multicolumn{3}{|c|}{ 11-Dehydrocorticosterone (ng/ml) } & & \multicolumn{3}{|c|}{ 11-Dehydrocorticosterone $(\mathrm{ng} / \mathrm{ml})$} \\
\hline & Mean \pm S.D. & C.V. $(\%)$ & $n$ & & Mean \pm S.D. & C.V. $(\%)$ & $n$ \\
\hline 7 & $12.3 \pm 0.40$ & 3.3 & 4 & 10 & $16.4 \pm 1.0$ & 6.2 & 4 \\
\hline 8 & $32.4 \pm 0.64$ & 2.0 & 4 & 11 & $27.1 \pm 2.16$ & 8.0 & 4 \\
\hline 9 & $80.5 \pm 2.31$ & 2.9 & 4 & 12 & $75.6 \pm 5.91$ & 7.8 & 4 \\
\hline
\end{tabular}

terone. Both methods are useful for measuring $11 \beta$-HSD activities in combination with the determination of serum corticosterone in rats and mice. Recently, the intracellular regeneration of glucocorticoids by $11 \beta$-HSDs has attracted much attention as a risk factor of metabolic syndrome ${ }^{2,11,35)}$ and is a key role in regulating the hypothalamic-pituitary-adrenal axis. $^{33,34,36,37)}$ Studies using experimental models of mice or rats whose $11 \beta$-HSDs are genetically modified have been carried out $^{33,34,38)}$; therefore, the proposed ELISA would be also applicable for measurements of serum 11-dehydrocorti- costerone in those animals. Further studies on the evaluation of $11 \beta$-HSD activities in serum and various experiments employing the ELISA presented here are in progress in our laboratory.

Acknowledgements We greatly appreciate the valuable comments of Dr. Shane Brown (Sydney, Australia). We wish to thank Miss Akiko Konaka and Miss Nami Domoto for their helpful technical support. This work was supported in part by Grants-in-Aid for the Center for Advanced Research 
and Technology of Kobe Pharmaceutical University from the Ministry of Education, Culture, Sports, Science and Technology of Japan.

\section{REFERENCES}

1) Seck1 J. R., Walker B. R., Trends Endocrinol. Metab., 15, 418-424 (2004).

2) Tomlinson J. W., Walker E. A., Bujalska I. J., Draper N., Lavery G. G., Cooper M. S., Hewison M., Stewart P. M., Endocr. Rev., 25, 831-866 (2004).

3) Draper N., Stewart P. M., J. Endocrinol., 186, 251-271 (2005).

4) Krozowski Z., Li K. X., Koyama K., Smith R. E., Obeyesekere V. R., Stein-Oakley A., Sasano H., Coulter C., Cole T., Sheppard K. E., J. Steroid Biochem. Mol. Biol., 69, 391-401 (1999).

5) Seckl J. R., Curr. Opin. Pharmacol., 4, 597-602 (2004).

6) Seckl J. R., Morton N. M., Chapman K. E., Walker B. R., Recent Prog. Horm. Res., 59, 359-393 (2004).

7) Quinkler M., Stewart P. M., J. Clin. Endocrinol. Metab., 88, 2384 2392 (2003).

8) Bujalska I., Shimojo M., Howie A., Stewart P. M., Steroids, 62, 7782 (1997).

9) Stewart P. M., Murry B. A., Mason J. I., J. Clin. Endocrinol. Metab., 79, 480- 484 (1994)

10) Stewart P. M., Boulton A., Kumar S., Clark P. M., Shackleton C. H., J. Clin. Endocrinol. Metab., 84, 1022-1027 (1999).

11) Rask E., Walker B. R., Soderberg S., Livingstone D. E., Eliasson M., Johnson O., Andrew R., Olsson T., J. Clin. Endocrinol. Metab., 87, 3330-3336 (2002).

12) Rask E., Olsson T., Soderberg S., Andrew R., Livingstone D. E., Johnson O., Walker B. R., J. Clin. Endocrinol. Metab., 86, 1418-1421 (2001).

13) Alberts P., Ronquist-Nii Y., Larsson C., Klingstrom G., Engblom L., Edling N., Lidell V., Berg I., Edlund P. O., Ashkzari M., Sahaf N., Norling S., Berggren V., Bergdahl K., Forsgren M., Abrahmsen L., Horm Metab. Res., 37, 402-407 (2005).

14) Schoneshofer M., Weber B., Oelkers W., Nahoul K., Mantero F., Clin. Chem., 32, 93-96 (1986).

15) Horigome H., Hirano T., Oka K., Life Sci., 69, 2429-2438 (2001).

16) Cook D. M., Kendall J. W., Greer M. A., Kramer R. M., Endocrinology,
93, 1019-1024 (1973).

17) Erlanger B. F., Borek F., Beiser S. M., Lieberman S., J. Biol. Chem., 234, 1090-1094 (1959)

18) Tagawa N., Saiki K., Kobayashi Y., Biol. Pharm. Bull., 24, 867-871 (2001).

19) Erlanger B. F., Borek F., Beiser S. M., Lieberman S., J. Biol. Chem., 228, 713-727 (1957).

20) Nishiguchi Y., Kobayashi Y., Tagawa N., Miyai K., Watanabe F., Steroids, 57, 178-182 (1992).

21) Heyns W., Baelen H., Moor P. D., Clin. Chim. Acta, 18, 361-370 (1967).

22) Tagawa N., Tamanaka J., Fujinami A., Kobayashi Y., Takano T., Fukata S., Kuma K., Tada H., Amino N., Clin. Chem., 46, 523-528 (2000).

23) Tagawa N., Ohta M., Nakamura N., Nakano K., Hiroshi O., Kobayashi Y., Biol. Pharm. Bull., 25, 1634-1638 (2002).

24) Foster L. B., Dunn R. T., Clin. Chem., 20, 365-368 (1974).

25) Kane J. W., Ann. Clin. Biochem., 16, 209-212 (1979).

26) Hosoda H., Karube T., Kobayashi N., Nambara T., Chem. Pharm. Bull., 33, 249-255 (1985).

27) Schapiro S., Geller E., Eiduson S., Proc. Soc. Exp. Biol. Med., 109, 937-941 (1962)

28) Oliver C., Boudouresque F., Lacroix O., Anglade G., Grino M., Endocr. Regul., 28, 67-72 (1994).

29) Leal A. M., Carvalho J., Moreira A. C., Horm. Res., 52, 25-29 (1999).

30) Bartova A., Gen. Comp. Endocrinol., 10, 235-259 (1968)

31) Henning S. J., Am. J. Physiol., 235, E451-456 (1978).

32) Tagawa N., Katagiri M., Kobayashi Y., Steroids, 71, 165-170 (2006).

33) Yau J. L., Noble J., Kenyon C. J., Hibberd C., Kotelevtsev Y., Mullins J. J., Seck1 J. R., Proc. Natl. Acad. Sci. U.S.A., 98, 4716-4721 (2001).

34) Harris H. J., Kotelevtsev Y., Mullins J. J., Seckl J. R., Holmes M. C., Endocrinology, 142, 114-120 (2001).

35) Masuzaki H., Paterson J., Shinyama H., Morton N. M., Mullins J. J., Seckl J. R., Flier J. S., Science, 294, 2166-2170 (2001).

36) Johnstone H. A., Wigger A., Douglas A. J., Neumann I. D., Landgraf R., Seckl J. R., Russell J. A., J. Neuroendocrinol., 12, 811-822 (2000).

37) Mattsson C., Lai M., Noble J., McKinney E., Yau J. L., Seckl J. R., Walker B. R., Endocrinology, 144, 2997-3003 (2003).

38) Livingstone D. E., Jones G. C., Smith K., Jamieson P. M., Andrew R., Kenyon C. J., Walker B. R., Endocrinology, 141, 560—563 (2000). 